\title{
IN VITRO PROPAGATION OF Casearia sylvestris SWARTZ (SALICACEAE)
}

\author{
PROPAGAÇÃO IN VITRO DE Casearia sylvestris SWARTZ (SALICACEAE)
}

\author{
Juçara Terezinha Paranhos ${ }^{1}$ Lisiane löbler $^{2}$ Joanei Cechin $^{3}$ Tiéle Stüker Fernandes ${ }^{3}$ Elvis Fao ${ }^{4}$ \\ Hilda Hildebrand Soriani ${ }^{5}$
}

\begin{abstract}
In order to do an in vitro propagation of Casearia sylvestris, a tree native to Brazilian forests, studies of in vitro seed germination were performed and aseptic seedlings obtained were used as explant donors for micropropagation. Mature and immature seeds, stored for 10 days at 10 or $25^{\circ} \mathrm{C}$ were inoculated in medium containing $10 \%$ of MS salts and kept in the light (a 16-hour photoperiod) or continuous dark, at $25^{\circ} \mathrm{C}$. For immature seeds, gibberellic acid $\left(\mathrm{GA}_{3}\right)$ was or was not tested at a concentration of $1.5 \mathrm{mg} \mathrm{l}^{-1}$. From the seedlings obtained, the cotyledon and apical segments were removed and cultured in complete MS medium with five combinations of 6-benzylaminopurine (BAP) and naphthalene acetic acid (NAA): $0.0 ; 0.25 ; 0.5$; $1.0 ; 2.0$ and $0.0 ; 0025 ; 0.05 ; 0.1 ; 0.2 \mathrm{mg} \mathrm{L}-1$, respectively. The aerial shoots formed in vitro were cultured in MS medium containing 0.0 or $1.5 \mathrm{mg} \mathrm{L}^{-1}$ indole-3-butyric acid (IBA) for rooting. The highest percentage of germination $(60 \%)$ occurred in mature seeds exposed to light, regardless of other treatments, and may be considered positive photoblastic. The highest percentage of germination of immature seeds (27\%) occurred when previously stored at $10^{\circ} \mathrm{C}$ with or without $\mathrm{GA}_{3}$. The induction of aerial shoots was more efficient in apical segments in a medium containing the lowest combination of BAP and NAA or free of these growth regulators. The higher number of roots occurred in aerial shoots obtained from cotyledon segments, with or without IBA. After acclimatization, $83 \%$ of the plants survived.
\end{abstract}

Keywords: in vitro seed germination; micropropagation; growth regulators; light regimes.

\section{RESUMO}

Com o objetivo obter a propagação in vitro de Casearia sylvestris, árvore nativa das florestas brasileiras, estudos de germinação in vitro das sementes foram realizados e as plântulas assépticas obtidas foram usadas como doadoras de explantes na micropropagação. Sementes maduras e imaturas, armazenadas por 10 dias a 10 ou $25^{\circ} \mathrm{C}$ foram inoculadas em meio contendo $10 \%$ de sais de MS e mantidas na luz (fotoperíodo de 16 horas) ou escuro contínuo, a $25^{\circ} \mathrm{C}$. Para sementes imaturas, testou-se ou não ácido giberélico $\left(\mathrm{GA}_{3}\right)$ na concentração de $1,5 \mathrm{mg} \mathrm{l}^{-1}$. Das plântulas obtidas, segmentos cotiledonares e apicais foram retirados e cultivados em meio MS completo com cinco combinações de 6-benzilaminopurina (BAP) e ácido naftalenoacético (ANA): 0,$0 ; 0,25 ; 0,5 ; 1,0 ; 2,0$ e 0,$0 ; 0025 ; 0,05 ; 0,1 ; 0,2 \mathrm{mg} \mathrm{L}^{-1}$, respectivamente. As brotações aéreas formadas in vitro foram cultivadas em meio MS contendo 0,0 ou 1,5 $\mathrm{mg} \mathrm{L}^{-1}$ de ácido

1 Engenheira Agrônoma, $\mathrm{Dr}^{\mathrm{a}}$, Professora Associada do Departamento de Biologia, Centro de Ciências Naturais e Exatas, Universidade Federal de Santa Maria, Av. Roraima, 1000, CEP 97105-900, Santa Maria (RS), Brasil. jtparanhos@gmail.com

2 Bióloga, Mestranda do Programa de Pós-graduação em Agrobiologia, Centro de Ciências Naturais e Exatas, Universidade Federal de Santa Maria, Av. Roraima, 1000, CEP 97105-900, Santa Maria (RS), Brasil. lisilobler@gmail.com

3 Acadêmico do Curso de Agronomia, Centro de Ciências Rurais, Universidade Federal de Santa Maria, Av. Roraima, 1000, CEP 97105-900, Santa Maria (RS), Brasil. joaneicechin@yahoo.com.br / tielefernandes@hotmail.com

4 Acadêmico do Curso de Ciências Biológicas, Centro de Ciências Naturais e Exatas, Universidade Federal de Santa Maria, Av. Roraima, 1000, CEP 97105-900, Santa Maria (RS), Brasil.

5 Bióloga, $\mathrm{Dr}^{\mathrm{a}}$, Professora Adjunta do Departamento de Engenharia Florestal, Centro de Educação Superior Norte, Universidade Federal de Santa Maria, Linha 7 de Setembro, s/n BR 386, Km 40, CEP 98400-000, Frederico Westphalen (RS), Brasil. hildasoriani@gmail.com 
indol-3-butírico (IBA) para o enraizamento. O maior percentual de germinação (60\%) ocorreu em sementes maduras expostas à luz, independentemente dos demais tratamentos, podendo ser consideradas fotoblásticas positivas. A maior percentagem de germinação das sementes imaturas (27\%) ocorreu quando previamente armazenadas a $10^{\circ} \mathrm{C}$, com ou sem $\mathrm{GA}_{3}$. A indução de brotos aéreos foi mais eficiente em segmentos apicais e em meio contendo a menor combinação de BAP e ANA ou isento destes reguladores de crescimento. O maior número de raízes ocorreu em brotos obtidos a partir de segmentos cotiledonares, com ou sem AIB. Após a aclimatização, $83 \%$ das plantas sobreviveram.

Palavras-chave: germinação in vitro de sementes; micropropagação; reguladores de crescimento; regimes de luz.

\section{INTRODUCTION}

Casearia sylvestris Swartz (Salicaceae) is a tree found in practically all the forest formations in Brazil (BACKES; IRGANG, 2002), known by several common names such as carvalinho, chá de bugre, guaçatonga, porangaba, café-bravo. It is an important species for mixed reforestation of degraded areas and riparian forests (LORENZI; MATOS, 2008), having been listed, according to Vieira et al. (2002), as one of the priority tree species for conservation and sustainable management. The phytochemical and pharmacological action of the species, mainly of its leaves, have been studied due to its use in folk medicine, where the infusion of its bark is widely used as an anti-rheumatic, anti-inflammatory and antiophidian (WERLE et al., 2009). Phytochemical studies reported that hydroalcoholic extracts or isolated compounds showed anti-tumor activity, lowered blood triglyceride levels and controlled outbreaks of herpes simplex (ITOKAWA et al., 1990; MORITA et al., 1991; SILVA et al., 2008; WERLE et al., 2009).

The high extraction of this species in natural areas both for use in folk medicine and for reforestation, promotes degradation of the native flora and ecosystem disturbances (IMATOMI et al., 2009). This process can be considered partially sustainable, since this species is not cultivated and there is little basic information about the propagation and production of viable plants. In this context, there is a need to understand the spread of this native species in order to preserve and enhance its productive potential and to reverse the condition of partial sustainability. Therefore, it is essential to implement programs for the production of high quality seeds and seedlings, facilitating large-scale cultivation and a more rational use of these resources.

In general, arboreal plants present more easy propagation through seed germination (BACKES; IRGANG, 2002). However, this germination is often considered low due to low viability or dormancy. Both sexual and vegetative studies of in vitro propagation are important, since the environment is completely controlled, making it possible to obtain viable seedlings regardless of the season. However, most native species host specific microorganisms, impairing the in vitro regeneration of plants due to high contamination.

The in vitro germination of seeds may constitute the first step in an in vitro growth system to obtain aseptic explants (SOUSA et al., 2007; KIELSE et al., 2009; LAMB et al., 2011). Among in vitro, growth techniques, micropropagation has shown the greatest impact because it helps to obtain healthy plants that are difficult to propagate through conventional methods in a shorter period of time (DUTRA et al., 2009).

This study was designed with the objective of establishing protocols for in vitro propagation of Casearia sylvestris Swartz, by studying seed germination and subsequent use of aseptic seedlings in micropropagation studies.

\section{MATERIAL AND METHODS}

The experiments were performed at the Laboratory of Vegetal Tissue Growth at the Department of Biology of the Universidade Federal de Santa Maria.

For the in vitro seed germination study, fruits were collected from plants from the campus of the university. Seeds were removed and separated into two groups: mature seeds (light brown color) and immature seeds (greenish cream color), and then stored for ten days at two temperatures $\left(10\right.$ and $25^{\circ} \mathrm{C}$ \pm 1 ). Under aseptic conditions, the seeds were sterilized in $70 \%$ ethanol for one minute and in a solution of $2 \%$ sodium hypochlorite for 20 minutes. After three washes in distilled and autoclaved water, seeds 
were inoculated in medium containing 10\% of MS salts (MURASHIGE; SKOOG, 1962), free of organic substances, plus $15 \mathrm{~g} \mathrm{~L}^{-1}$ of sucrose. After adjustment of the $\mathrm{pH}$ to 5.8, the culture medium was solidified with agar $\left(6 \mathrm{~g} \mathrm{~L}^{-1}\right)$ and autoclaved for $20 \mathrm{~min}$ at $120^{\circ} \mathrm{C}$ and $1.5 \mathrm{~atm}$.

Mature seeds were inoculated into two kinds of containers (test tube and culture flask, measuring $150 \mathrm{~mm} \times 20 \mathrm{~mm}$ and $80 \mathrm{~mm} \times 40 \mathrm{~mm}$, respectively) and were kept in growth chambers at $25 \pm 1^{\circ} \mathrm{C}$ under two regimes of light, continuous darkness and a photoperiod of $16 \mathrm{~h}$ (R.F.A. of $\sim 73 \mu \mathrm{mol} \mathrm{m} \mathrm{m}^{-2} \mathrm{~s}^{-1}$, white fluorescent lamps). Immature seeds were inoculated in test tubes containing the same culture medium, supplemented or not with the plant regulator gibberellic acid $\left(\mathrm{GA}_{3}\right), 1.5$ or $0.0 \mathrm{mg} \mathrm{L}^{-1}$ (control), and maintained on a photoperiod of $16 \mathrm{~h}$ at $25 \pm 1^{\circ} \mathrm{C}$.

Seed germination was evaluated weekly for radicle emergence (BORGHETTI; FERREIRA, 2004). Green light was used to evaluate seeds kept in continuous darkness. The experimental design was completely randomized, with factors for mature seeds being type of container, seed storage temperature and light regime arranged in a tri-factorial scheme, with eight treatments and four replicates of 25 seeds. For the immature seeds, the factor storage temperature and dose of $\mathrm{GA}_{3}$ comprised a bi-factorial scheme with four treatments and four replicates of 50 seeds.

Aseptic seedlings originating from in vitro germination of mature seeds were used as donors of nodal segments (cotyledon and apical) to study micropropagation. Explants were inoculated in test tubes measuring $150 \mathrm{~mm}$ × $20 \mathrm{~mm}$, containing complete MS medium plus $30 \mathrm{~g} \mathrm{~L}^{-1}$ de sucrose, $10 \mathrm{~g} \mathrm{~L}^{-1}$ polyvinylpyrrolidone (PVP) and solidified with $6 \mathrm{~g} \mathrm{~L}^{-1}$ of agar. The $\mathrm{pH}$ was adjusted to 5.8 and the medium was autoclaved for $20 \mathrm{~min}$ at $120^{\circ} \mathrm{C}$ and $1.5 \mathrm{~atm}$. Five combinations of 6-benzylaminopurine (BAP) and naphthalene acetic acid (NAA) were studied: $0.0 ; 0.25 ; 0.5 ; 1.0 ; 2.0 \mathrm{mg} \mathrm{L}^{-1}$ and $0.0 ; 0.025 ; 0.05 ; 0.1 ; 0.2 \mathrm{mg}$ $\mathrm{L}^{-1}$, respectively. The explant types and combinations of growth regulators were arranged in a bi-factorial scheme, totaling ten treatments with three replicates each and 15 explants per replicate.

The cultures remained in a growth chamber, at a temperature of $25 \pm 1{ }^{\circ} \mathrm{C}$ and photoperiod of 16 $\mathrm{h}$, for 45 days, when the regenerated aerial shoots were transferred to test tubes with the same dimensions, containing $15 \mathrm{~mL}$ of complete MS medium, $30 \mathrm{~g} \mathrm{~L}^{-1}$ of sucrose, $6 \mathrm{~g} \mathrm{~L}^{-1}$ of agar and $\mathrm{pH}$ 5.8. Two concentrations of indole-3-butyric acid (IBA) were tested, 0.0 (control) and $1.5 \mathrm{mg} \mathrm{L}^{-1}$, keeping the source of the initial seedlings. After 30 days, root emergence at the base of the sprouts and the number of adventitious roots formed were evaluated.

In all studies, the data in percentage were transformed into $\log 10$ for the application of variance analysis and the comparison between means was performed using the Duncan test $(p \leq 0.05)$, with the aid of SPSS (Statistical Package for Social Science) statistics program, version 10 (PEREIRA, 2003).

Complete plants obtained in vitro were transferred to polypropylene trays $(1600 \mathrm{~mL})$ with six perforations in the base and Plantmax ${ }^{\circledR}$ substrate + vermiculite at a 2:1 ratio (autoclaved twice for 50 min before use, with a 24-hour interval). The samples were sealed with Parafilm, which was removed gradually to expose the plants to ex vitro conditions before total removal. Trays, each with 10 plants, remained in the growth chamber at $25 \pm 1^{\circ} \mathrm{C}$ on a photoperiod of $16 \mathrm{~h}\left(\mathrm{RFA} \sim 36 \mu \mathrm{mol} \mathrm{m} \mathrm{m}^{-2} \mathrm{~s}^{-1}\right)$, receiving irrigation with distilled water and autoclaving when needed. After 30 days of growth, the plants were transferred to polyethylene pots $(600 \mathrm{~mL})$, one per pot, containing the same substrate, with daily irrigation with distilled water. At 45 days of growth the survival rate of the plants was evaluated.

\section{RESULTS AND DISCUSSION}

Regardless of the type of container used, mature seeds previously stored for 10 days at temperatures of 10 or $25^{\circ} \mathrm{C}$, were found to be positive photoblastic (Figure 1). In all treatments, seeds exposed to light (photoperiod of 16 hours) presented the greatest percentage of germination, on average $60 \%$, not statistically differing $(\mathrm{p} \leq 0.05)$ among themselves, but differing from treatments under continuous darkness, where the highest germination rate was $4 \%$. These results do not corroborate with those obtained by Rosa and Ferreira (2001), who investigated germination of many native species of Rio Grande do Sul state and observed that the seeds of this species germinated, regardless of the light regime, classifying them as neutral photoblastic. Imatoni et al. (2009) investigated the germination of Casearia sylvestris seeds from two regions, Paraná and São Paulo, and observed that seeds originating from Parana did not germinate in the dark at a temperature of 
$33^{\circ} \mathrm{C}$ and in all treatments the percentages of germination did not exceed $40 \%$. According to the authors, the germination capacity of a species varies in accordance with the environmental conditions of the population of origin.

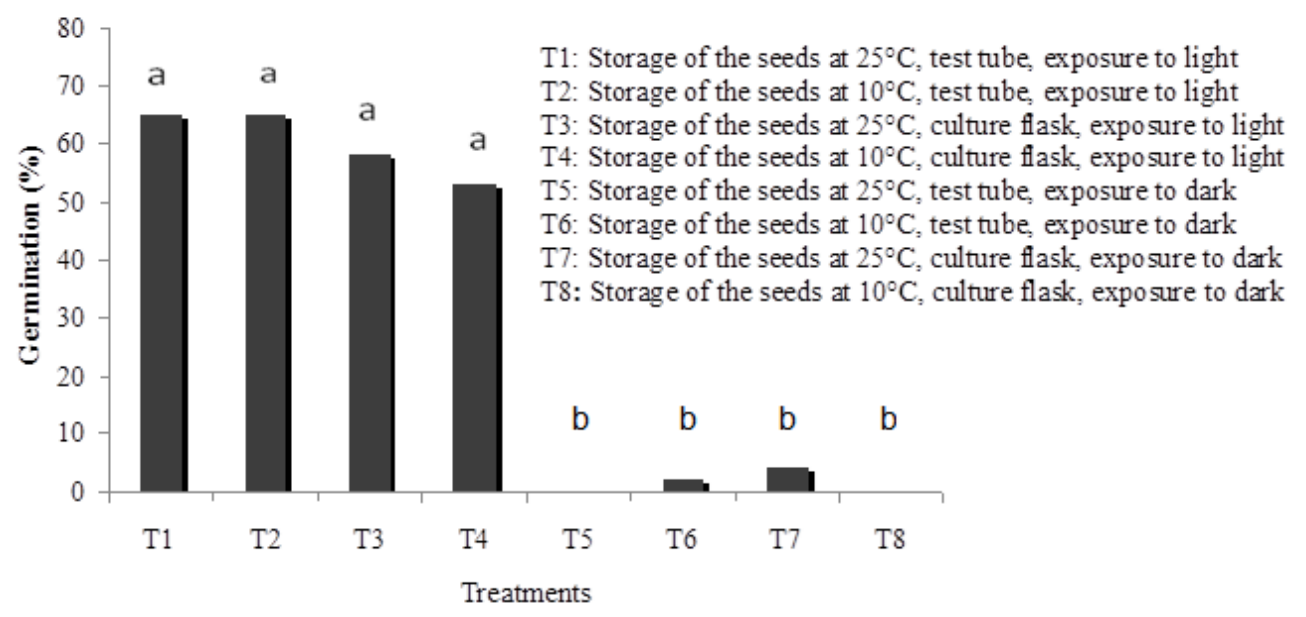

FIGURE 1: Average percentage of the in vitro germination of mature seeds Casearia sylvestris inoculated in nutritive medium containing 10\% of MS salts (MURASHIGE; SKOOG, 1962), testing different treatments: seed storages at $10^{\circ} \mathrm{C}$ or $25^{\circ} \mathrm{C}$ for ten days, two types of container and two light regimes. There were used four replications per treatment and 25 seeds per replicate. Same letters do not differ by the Duncan test $(\mathrm{p} \leq 0.05)$.

FIGURA 1: Percentagem média de germinação in vitro de sementes maduras de Casearia sylvestris, inoculadas em meio nutritivo contendo 10\% dos sais MS (MURASHIGE; SKOOG, 1962), testando-se diferentes tratamentos: armazenamento das sementes a $10^{\circ} \mathrm{C}$ ou $25^{\circ} \mathrm{C}$ por 10 dias, dois tipos de recipiente e dois regimes de luz. Foram utilizadas quatro repetições por tratamento e 25 sementes por repetição. Letras iguais não diferem pelo Teste de Duncan $(\mathrm{p} \leq 0,05)$.

Casearia sylvestris has a long flowering and fruiting period throughout the year (BACKES; IRGANG, 2002), causing fruit, and consequently seed, maturation to be heterogeneous, influencing the intrinsic characteristics of the seeds. Thus, along with the collection of ripe fruits, it is possible to gather fruit with immature seeds. Seeds of immature fruits, previously stored at two temperatures $\left(10\right.$ or $\left.25^{\circ} \mathrm{C}\right)$, were germinated in culture medium and light regimes, similar to those used for the mature seeds, testing for the presence or absence of $\mathrm{GA}_{3}\left(1.5 \mathrm{mg} \mathrm{L}^{-1}\right)$. Gibberellic acid is a growth regulator widely used for acceleration and uniform germination of various species, as it activates hydrolytic enzymes involved in the breakdown of plant reserve substances, stimulating embryo maturation (ZAIDAN; BARBEDO, 2004; TAIZ; ZEIGER, 2013). However, Figure 2 shows that in this study, $\mathrm{GA}_{3}$ did not promote the germination of immature seeds, which was influenced only by storage temperature. The highest germination percentage (27 and 22\%) occurred in seeds previously stored at $10^{\circ} \mathrm{C}$, regardless of the presence or absence of the growth regulator, without a significant difference $(\mathrm{p} \leq 0.05)$ among themselves, however, differing from the seeds stored at $25^{\circ} \mathrm{C}$. According to Baskin and Baskin (1998), seeds of many species, after being dispersed from the mother plant, do not germinate until experiencing a period of after-ripening. Treatment at low temperatures appears to promote the germination of these seeds, overcoming dormancy through a combination of physiological changes in the embryo and its surrounding tissues (HARTMANN et al., 2002).

Seeds treated with this growth regulator and stored at $10^{\circ} \mathrm{C}$ (Figure 2) presented a lower germination percentage than untreated seeds. This may be due to phytotoxicity of this growth regulator, since low temperatures stimulate its endogenous production and germination of some non-domesticated

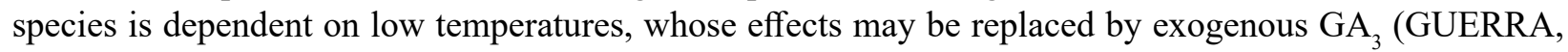
2004). However, responses to $\mathrm{GA}_{3}$ in seed germination are dependent on the species studied and on the 


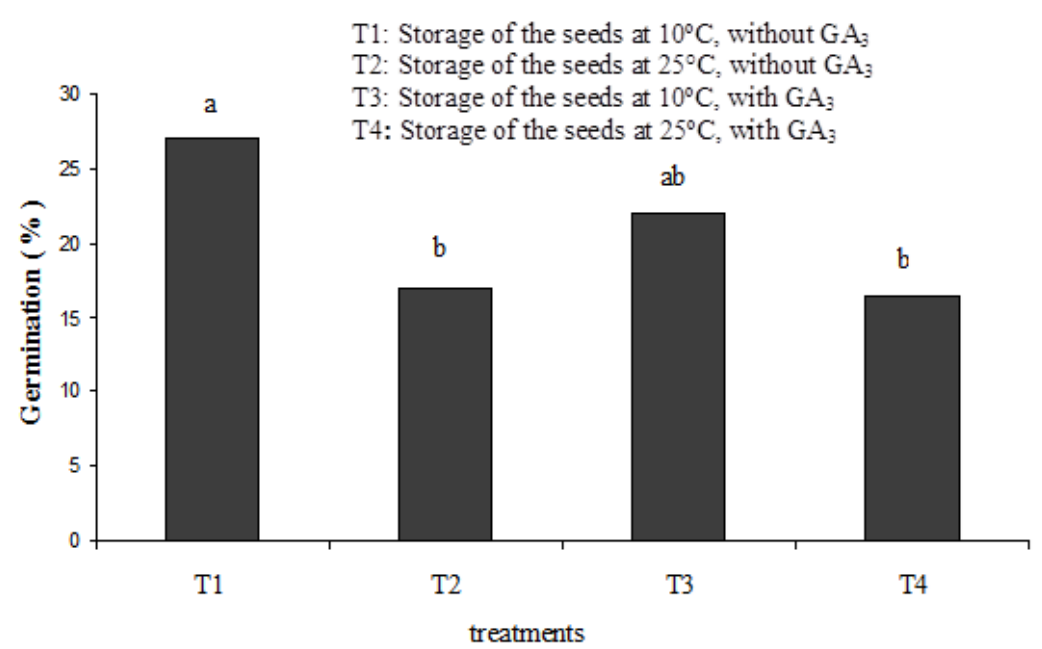

FIGURE 2: Average percentage of in vitro germination of immature Casearia sylvestris seeds subjected to different treatments: seeds stored at $10^{\circ} \mathrm{C}$ or $25^{\circ} \mathrm{C}$ for ten days in the presence or absence of $1.5 \mathrm{~m} \mathrm{~L}^{-1}$ of gibberellic acid $\left(\mathrm{GA}_{3}\right)$ in medium containing $10 \%$ of MS salts (MURASHIGE; SKOOG, 1962), with four replicates per treatment and 50 seeds per replicate. Same letters do not differ by the Duncan test $(\mathrm{p} \leq 0.05)$.

FIGURA 2: Percentagem média da germinação in vitro de sementes imaturas de Casearia sylvestris submetidas a diferentes tratamentos: armazenamento das sementes a $10^{\circ} \mathrm{C}$ ou $25^{\circ} \mathrm{C}$ por dez dias e presença ou ausência de $1,5 \mathrm{~m} \mathrm{~L}^{-1}$ de Ácido Giberélico $\left(\mathrm{GA}_{3}\right)$, em meio contendo $10 \%$ dos sais MS (MURASHIGE; SKOOG, 1962). Foram utilizadas quatro repetições por tratamento e 50 sementes por repetição. Letras iguais não diferem pelo Teste de Duncan $(\mathrm{p} \leq 0,05)$.

concentrations used. In studies of in vitro seed germination of forest and/or fruit species, the use of $\mathrm{GA}_{3}$ in the culture medium at different doses did not improve the performance of seed germination (CALGAROTO et al., 2007; IMATOMI et al., 2009; MENEZES et al., 2010).

Aseptic seedlings obtained from in vitro germination of mature seeds on a photoperiod of $16 \mathrm{~h}$ were used as donors of nodal segments (cotyledon and apical) to study plant micropropagation, testing five combinations of NAA and BAP. Figure 3 shows that regardless of the type of explant used, the highest number of aerial shoots occurred in medium without growth regulators and in combination with lower concentrations of BAP and NAA $\left(0.25 \mathrm{mg} \mathrm{L}^{-1}\right.$ and $0.025 \mathrm{mg} \mathrm{L}^{-1}$, respectively), ranging from 14.5 to 15 aerial shoots per explant, with no differences among them $(\mathrm{p} \leq 0.05)$. These values differed significantly from combinations with higher concentrations of BAP (1.0 to $\left.2.0 \mathrm{mg} \mathrm{L}^{-1}\right)$ and NAA $(0.1$ and $\left.0.2 \mathrm{mg} \mathrm{L}^{-1}\right)$, which varied from one to six aerial shoots per explant. The medium containing $0.5 \mathrm{mg} \mathrm{L}^{-1} \mathrm{BAP}+$ $0.05 \mathrm{mg} \mathrm{L}^{-1} \mathrm{NAA}$ was effective for the formation of aerial shoots in cotyledon segments (12 per explant), but differed significantly from that of apical segments (five per explant).

The differentiation and growth control of in vitro tissue cultures is ascribed to the balance between auxins and cytokinins, which yield enhanced development when utilized in adequate dosages (REZENDE et al., 2011). However, this species, although it has an arboreal habit when adult (BACKES; IRGANG, 2002), the donor seedlings of explants allow the formation of aerial shoots in vitro without the use of growth regulators or at low concentrations. The addition of growth regulators has the primary aim of meeting possible deficiencies of endogenous explants isolated from the mother plants. However, this depends on the physiological response of the explant (GRATTAPAGLIA; MACHADO, 1998). The induction of aerial shoots or even of complete plants in medium free of growth regulators may be related to the fact that these explants were taken from seedlings obtained from in vitro germination. Similar results were reported in other studies of micropropagation of tree species (VICTÓRIO et al., 2008; KIELSE et al., 2009; FLORES et al., 2009). 


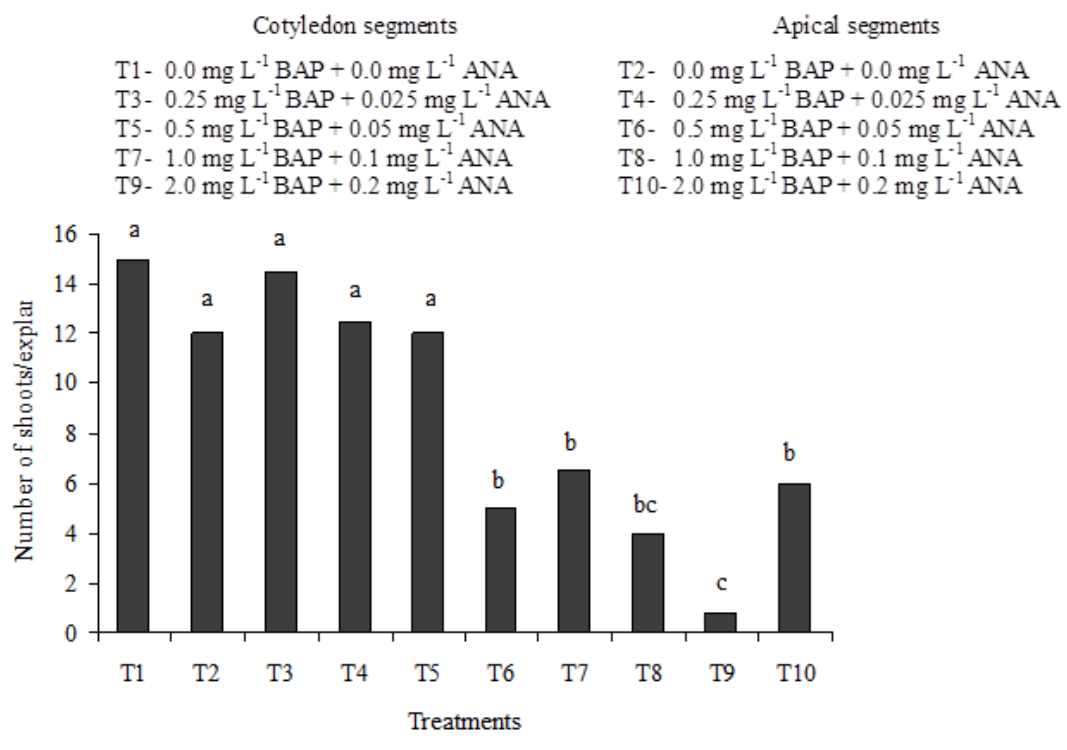

FIGURE 3: Number of aerial shoots per explant (cotyledon segments and/or apical segments), subjected to different combinations of 6-benzylaminopurine (BAP) and naphthalene acetic acid (NAA), totaling ten treatments, with three replicates per treatment and 15 explants per replicate. Same letters do not differ by the Duncan test $(\mathrm{p} \leq 0.05)$.

FIGURA 3: Número de brotações por explante (segmento cotiledonar e/ou segmento apical), submetidos a diferentes combinações de 6-benzil amino purina (BAP) e ácido naftaleno acético (ANA), totalizando dez tratamentos. Foram utilizadas três repetições por tratamento e 15 explantes por repetição. Letras iguais não diferem pelo Teste de Duncan $(\mathrm{p} \leq 0.05)$.

In this study with Casearia sylvestris, the treatments did not promote the formation of complete plants. The in vitro aerial shoots were transferred to an induction medium for adventitious rooting, keeping the source of explants (cotyledon segments and/or apical segments) in the absence or presence of IBA $\left(1.5 \mathrm{mg} \mathrm{L}^{-1}\right)$. Figure 4 shows the results of the adventitious rooting, which was small for all treatments, however, it observed that the origin of the shoots influenced the formation of roots, regardless of the presence or absence of IBA. The largest numbers of rooted shoots occurred in those originated from cotyledon segments, not differing significantly $(\mathrm{p} \leq 0.05)$ among shoots derived from apical segments, and there was no need for an exogenous source of auxin for the induction of adventitious roots. However, the aerial shoots from apical segments treated with IBA had a better response to rooting, nearly doubling the number of rooted shoots. The obtainment of micropropagated plants in two steps was also reported by Gomes et al. (2010), in a study on in vitro propagation of Maclura tinctoria (Moraceae), where the maximum shoot formation was obtained when $5.37 \mu \mathrm{M}$ NAA $+4.45 \mu \mathrm{M}$ BAP was used and root formation was observed on explants inoculated in WPM and supplemented with $23.62 \mu \mathrm{M}$ IBA $+4.7 \mathrm{~g} \mathrm{~L}^{-1}$ activated charcoal. Fermino Junior and Scherwinski-Pereira (2012), using nodal segments from seedlings germinated in vitro in the micropropagation of Amburana acreana (Fabaceae), found that the formation of the largest number of aerial shoots occurred with $4.0 \mathrm{mg} \mathrm{L}^{-1}$ of BAP and the formation of a greater number of roots occurred with $0.5 \mathrm{mg} \mathrm{L}^{-1}$ of IBA.

According to Fachinello et al. (1995), during the formation of adventitious roots there is an interaction between the auxin provided and the factors that synergistically act in these roots. Endogenous auxins are synthesized in buds and young leaves, being transported via the phloem to other plant organs. Ford et al. (2002) suggest that the IBA exogenously applied is rapidly transported to the leaves, enabling a greater production of indole acetic acid (IAA), with subsequent transport to the root initiation region.

Thus, the obtainment of complete plants of Casearia sylvestris occurred in two stages, one of formation of aerial shoots followed by that of adventitious rooting. Complete plants were acclimatized and after 45 days of growth, the survival rate was $83 \%$ (data not shown). 


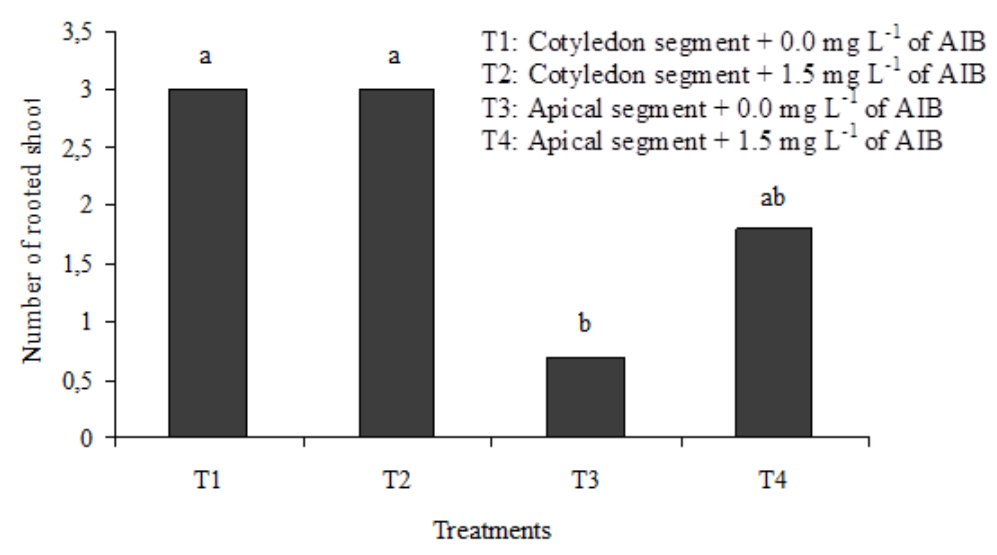

FIGURE 4: Number of rooted shoots in the presence and absence of indole-3-butyric acid (IBA), with three replicates per treatment and 18 explants per replicate. Same letters do not differ by the Duncan test $(\mathrm{p} \leq 0,05)$.

FIGURA 4: Número de brotações enraizadas na presença e ausência de ácido indolbutírico (AIB). Foram utilizadas três repetições por tratamento e 18 explantes por repetição. Letras iguais não diferem pelo Teste de Duncan $(\mathrm{p} \leq 0,05)$.

\section{CONCLUSION}

Mature seeds of Casearia sylvestris collected in the spring were positive photoblastic. Immature seeds collected in the spring presented a lower germination potential than the mature seeds, and this potential was greater when previously stored at temperatures of $10^{\circ} \mathrm{C}$, regardless of the presence or absence of $\mathrm{GA}_{3}$.

Cotyledon segments and apical segments removed from aseptic seedlings, obtained from the in vitro germination of seeds, were found to be effective for the micropropagation of Casearia sylvestris plants. In this species, the obtainment of micropropagated plants occurred in two steps: formation of aerial shoots followed by adventitious rooting. A larger number of formed aerial shoots occurred with combinations of lower doses of the growth regulators cytokinin and auxin or in their absence. The adventitious rooting of aerial shoots from cotyledon segments occurred even in the absence of indole-3-butyric acid. Complete plants obtained in vitro presented a high survival rate after acclimatization.

\section{REFERENCES}

BACKES, P.; IRGANG, B. Árvores do Sul: guia de identificação e interesse ecológico. 1st ed. Porto Alegre: [s.n.], 2002. 326 p.

BASKIN, C. C.; BASKIN, J. M. Seeds: ecology, biogeography, and evolution of dormancy and germination. San Diego: Academic Press, 1998.

BORGHETTI, F.; FERREIRA, A. G. Interpretação de resultados de germinação. In: FERREIRA, A. G.; BORGHETTI, F. (Orgs). Germinação: do básico ao aplicado. 1st ed. Porto Alegre: Artmed, 2004. 323 p.

CAlGAROTO, N. S. et al. Germinação in vitro de Sementes de Scutia buxifolia REISSEK. Revista Brasileira de Biociências, Porto Alegre, v. 5, n. 2, p. 357-359, 2007.

DUTRA, L. F. et al. A micropropagação do eucalipto. Pesquisa Florestal Brasileira, Colombo, v. 58, p. 49-59, 2009.

FACHINELlO, J. C. et al. Propagação de plantas frutíferas de clima temperado. 2nd ed. Pelotas: UFPEL, 1995. $178 \mathrm{p}$.

FERMINO JUNIOR, P. C. P.; SCHERWINSKI-PEREIRA, J. E. Germinação e Propagação in vitro de cerejeira (Amburana acreana (Ducke) A.C. Smith - Fabaceae). Ciência Florestal, Santa Maria, v. 22, n. 1, p. 1-9, 2012. 
FLORES, R. et al. Benzilaminopurina (BAP) e thidiazuron (TDZ) na propagação in vitro de Pfaffia glomerata (Spreng.) Pedersen. Revista Brasileira de Plantas Medicinais, Paulínia, v. 11, p. 292-299, 2009.

FORD, Y. Y. et al. Adventitious rooting: examining the role of auxin in easy- and a difficult-to-root plant. Plant Growth Regulation, Sydney, v. 36, p. 149-159, 2002.

GRATTAPAGLIA, D.; MACHADO, M. A. Micropropagação. In: TORRES, A. C. et al. Cultura de tecidos e transformação genética de plantas. Brasília: Embrapa Informação tecnológica; Embrapa Hortaliças, $1998.509 \mathrm{p}$.

GOMES, G. A. C. et al. Micropropagation of Maclura tinctoria L.: an endangered woody species. Revista Árvore, Viçosa, MG, v. 34, n. 1, p. 25-30, 2010.

GUERRA, M. P. Giberelinas. In: KERBAUY, G. B. Fisiologia vegetal. 1st ed. Rio de Janeiro: Guanabara Koogan, 2004. 452 p.

HARTMANN, H. T. et al. Plant propagation: principles and practices. 7th ed. New Jersey: Prentice Hall, 2002. $869 \mathrm{p}$.

IMATOMI, M. et al. Caracterização e comportamento germinativo de sementes de Casearia sylvestris Swartz (Salicaceae). Revista Brasileira de Sementes, Londrina, v. 31, n. 2, p. 36-47, 2009.

ITOKAWA, H. et al. New antitumor principles, casearins A-F from C. sylvestris Sw. (Flacourtiaceae). Chemical \& Pharmaceutical Bulletin, Tokyo, v. 38, p. 3384-3387, 1990.

KIELSE, P. et al. Regeneração in vitro de Parapiptadenia rigida. Ciência Rural, Santa Maria, v. 39, p. 1098-1104, 2009.

LAMB, C. R. C. et al. Regeneração de plantas a partir de segmentos de base de folhas em aveia. Ciência Rural, Santa Maria, v. 31, p. 751-755, 2011.

LORENZI, H.; MATOS, F. J. A. Plantas Medicinais do Brasil: nativas e exóticas cultivadas. 2nd ed. Nova Odessa: Instituto Plantarum, 2008. 544 p.

MENEZES, T. P. et al. Sacarose e GA na germinação de sementes e no desenvolvimento in vitro de plântulas de goiabeira 'Pedro Sato'. Plant Cell Culture \& Micropropagation, Lavras, v. 6, p. 69-75, 2010.

MORITA, H. et al. Structures and cytotoxic activity relationship of casearins, new clerodane diterpenes from Casearia sylvestris Sw. Chemical \& Pharmaceutical Bulletin, Tokyo, v. 39, p. 693-697, 1991.

MURASHIGE, T.; SKOOG, F. A revised medium for rapid growth and bioassays with tobacco tissue culture. Physiologia Plantarum, Copenhagen, v. 15, p. 473- 497, 1962.

PEREIRA, A. Guia Prático de Utilização do SPSS. Análise de dados para Ciências Sociais e Psicologia. 4th ed. Lisboa: Edições Silabo, 2003.

REZENDE, J. C. et al. Effects of auxins and cytokinins on the development of Coffea arabica L. somatic embryos. Plant Cell Culture \& Micropropagation, Lavras, v. 7, p. 1-8, 2011.

ROSA, S. G. T.; FERREIRA, A. G. Germinação de sementes de plantas lenhosas. Acta Botânica Brasílica, Belo Horizonte, v. 15, p. 147-154, 2001.

SILVA, S. L. et al. Cytotoxic evaluation of essential oil from Casearia sylvestris Sw. on human cancer cells and erythrocytes. Acta Amazônica, Manaus, v. 38, n. 1, p. 107-112, 2008.

SOUSA, C. S. et al. Germinação e Indução de Brotações in vitro utilizando diferentes reguladores vegetais em Mangabeira (Hancornia speciosa). Revista Brasileira de Biociências, Porto Alegre, v. 5, p. 276-278, 2007.

TAIZ, L.; ZEIGER, E. Fisiologia Vegetal. 5th ed. Porto Alegre: Artmed, 2013. 792 p.

VICTÓRIO, C. P. et al. Effects of auxins and cytokinins on in vitro development of Alpinia purpurata K. Schum and phenolic compounds production. Plant Cell Culture \& Micropropagation, Lavras, v. 4, p. 92-98, 2008.

VIEIRA, R. F. et al. Estratégias para conservação e manejo de recursos genéticos de plantas medicinais e aromáticas: resultados da primeira reunião técnica. Brasília: Embrapa Recursos Genéticos e Biotecnologia; Ibama; CNPq, 2002.

WERLE, A. L. B. et al. Avaliação da atividade de Casearia sylvestris Swartz (Flacourtiaceae) sobre os níveis séricos de triglicerídeos em ratos. Revista Brasileira de Farmacognosia, Curitiba, v. 19, p. 400-402, 2009.

ZAIDAN, L. B. P.; BARBEDO, C. J. Quebra de dormência em sementes. In: FERREIRA, A. G.; 
BORGHETTI, F. Germinação: do básico ao aplicado. Porto Alegre: Artmed, 2004. 323 p. 